\title{
Seasonal variation in equine follicular fluid proteome
}

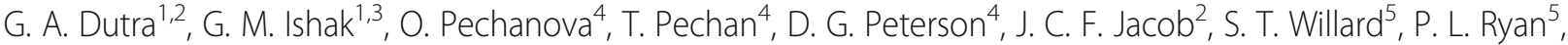 \\ E. L. Gastal ${ }^{1}$ and J. M. Feugang ${ }^{5^{*}}$
}

\begin{abstract}
Background: Proteomic studies of follicular fluid (FF) exist for several species, including the horse; however, the seasonal influence on FF proteome has not been explored in livestock. The application of high-throughput proteomics of FF in horse has the potential to identify seasonal variations of proteins involved in follicle and oocyte growth.
\end{abstract}

Methods: This study (i) profiles the proteomes of equine FF collected from dominant growing follicles during the spring anovulatory season (SAN), and spring (SOV), summer (SUM), and fall (FOV) ovulatory seasons; and (ii) identifies season-dependent regulatory networks and associated key proteins.

Results: Regardless of season, a total of 90 proteins were identified in FF, corresponding to 63, 72, 69, and 78 proteins detected in the SAN, SOV, SUM, and FOV seasons, respectively. Fifty-two proteins were common to all seasons, a total of 13 were unique to either season, and 25 were shared between two seasons or more. Protein-to-protein interaction (PPI) analysis indicated the likely critical roles of plasminogen in the SAN season, the prothrombin/plasminogen combination in SUM, and plasminogen/complement C3 in both SOV and FOV seasons. The apolipoprotein A1 appeared crucial in all seasons. The present findings show that FF proteome of SUM differs from other seasons, with FF having high fluidity (low viscosity).

Conclusions: The balance between the FF contents in prothrombin, plasminogen, and coagulation factor XII proteins favoring FF fluidity may be crucial at the peak of the ovulatory season (SUM) and may explain the reported lower incidence of hemorrhagic anovulatory follicles during the SUM season.

Keywords: Ovary, Follicle, Seasonality, Proteomics, Mares, horses

\section{Background}

Within the existing efforts to improve fertility in livestock and companion animals, a different knowledge is sought after to achieve a greater reproduction rate, especially for females. A lack of high-quality oocytes and reliable reproductive biomarkers $[1,2]$ represents an obstacle toward the success. Meanwhile, the high dynamic in the composition of the follicular fluid (FF) during follicular growth $[3,4]$ creates an opportunity for the identification of key molecules that are critical for oocyte developmental competence acquisition. Furthermore,

\footnotetext{
* Correspondence: jn181@ads.msstate.edu

${ }^{5}$ Department of Animal and Dairy Sciences, Mississippi State University,

Mississippi State, 4025 Wise Center, PO Box 9815, Mississippi State, MS 39762, USA

Full list of author information is available at the end of the article
}

the situation is even more challenging in horses, due to the obvious reproductive seasonality [4].

The ovarian activity of non-pregnant mares is continuously changing throughout the year, presenting periods of intense activity during summer, low activity during winter (deep anestrus phase), and irregular activity during spring and fall transitional seasons [5-7]. Results of previous studies have shown differences in preovulatory follicle diameter and blood flow [8-10], and hormonal concentrations among seasons [9]. Studying the effect of season on ovarian activity is important not only for better understanding of the follicular dynamics in mares but also for improving our knowledge regarding the follicular environment and biological processes associated with oocyte maturation and ovulation during different seasons of the year. Numerous reports have suggested

(c) The Author(s). 2019 Open Access This article is distributed under the terms of the Creative Commons Attribution 4.0 International License (http://creativecommons.org/licenses/by/4.0/), which permits unrestricted use, distribution, and reproduction in any medium, provided you give appropriate credit to the original author(s) and the source, provide a link to the Creative Commons license, and indicate if changes were made. The Creative Commons Public Domain Dedication waiver (http://creativecommons.org/publicdomain/zero/1.0/) applies to the data made available in this article, unless otherwise stated. 
the constant changes of the FF composition related to the physiological status of the growing follicle [11, 12], the physiological and health conditions of the animal [13-15], and the reproductive seasonality variation [16, 17]. These changes can influence the quality of growing oocytes and their readiness for successful fertilization and subsequent embryo development [18-20]. Moreover, investigating the seasonal variation of equine $\mathrm{FF}$ composition may help to better comprehend the mechanisms governing oocyte and follicle maturation, facilitating, therefore, assisted reproductive techniques.

High-throughput technologies (e.g., genomics, metabolomics, and proteomics) allow for in-depth investigations of complex samples such as FF, with potential for new biomarker discoveries, or strategies for intrafollicular treatment. Large-scale proteomics approaches (gel-based and gel-free) were applied to either profile or compare global proteomes of FF in cows [21, 22], humans [23, 24], pigs $[25,26], \operatorname{dogs}[27]$, and horses [28, 29]. Currently, the knowledge regarding equine FF proteome is deficient, and its relationship with fertility in mares is still unknown. Furthermore, the relationship of the equine FF dynamics composition with the reproductive seasonality in horses remains to be determined [4].

The aims of the present study were to (i) use the shotgun (gel-free) approach to evaluate the proteome profiles of equine FF collected from ovarian follicles (30-34 $\mathrm{mm}$ in diameter) at different seasons of the year (spring anovulatory or SAN, spring ovulatory or SOV, summer or SUM, and fall ovulatory or FOV); and (ii) apply comparative bioinformatics analyses to identify potential regulatory network differences.

\section{Methods}

\section{Animals}

Seventeen Quarter horse mares, 8 to 14 years old and weighing 400 to $600 \mathrm{~kg}$, were housed on pasture in the northern hemisphere $\left(37^{\circ} 42^{\prime} 37.53^{\prime \prime} \mathrm{N}, 89^{\circ} 13^{\prime}\right.$ 9.50" W),

under natural light conditions, with free access to fresh water and trace-mineralized salt. Animals were handled in accordance with the US Government Principles for the Utilization and Care of Vertebrate Animals Used in Testing, Research, and Training (https://grants.nih.Gov /grants/olaw /references/phspol.htm \#US GovPrinciples). This study was approved by the Institutional Animal Care and Use Committee (IACUC) of Southern Illinois University.

\section{Ultrasonographic examination and seasonal groups}

Follicular fluids were collected from dominant growing follicles during various seasons of the same year: March, as Spring Anestrus (SAN) representing the transition season when dominant anovulatory follicles are found after the deep anestrus season and before the spring ovulatory season; - Between April and May, as Spring Ovulatory (SOV) representing the beginning of the ovulatory season, with regular cycling of mares; Between June and July, as Summer (SUM) representing the middle of the ovulatory season, with maximum of ovarian cyclic activity expected; - and September, as Fall Ovulatory (FOV) representing the final period of the ovulatory season befor the transition to the fall anovulatory and deep anestrus seasons. In all four seasons, follicles $\geq 6 \mathrm{~mm}$ in diameter were ablated, as previously described [30], to induce a new follicular wave, allowing, therefore, proper tracking of growing/healthy follicles. During the SAN season, after follicle ablation, follicles of the new induced wave were daily tracked using an ultrasound machine (Aloka SSD-900; Aloka Co, Ltd., Wallingford, CT, USA) equipped with a multi-frequency 5$10 \mathrm{MHz}$ linear array transducer (Aloka UST-5821-7.5). Samples of FF ( $n=6$ follicles) were collected when the follicles reached $30-34 \mathrm{~mm}$ in diameter. During SOV, SUM, and FOV, mares were monitored daily with ultrasonography until ovulation; thereafter, follicle ablation was performed on day 10-12 after ovulation (day $0=$ ovulation) and follicle tracking of the new induced wave was performed daily to collect FF when a dominant follicle reached $30-34 \mathrm{~mm}$ in diameter. Samples of FF were aspirated during SOV, SUM, and FOV seasons $(n=6,6$, and 12 follicles, respectively). In all seasons, the presence of uterine edema (estrus-like) and the absence of a corpus luteum detected through ultrasonography at the moment of FF collection did qualify the animal for the procedure.

\section{Follicular fluid collection}

Samples of FF were collected using transvaginal ultrasound-guided follicle aspiration as recently reported [10]. Samples were immediately centrifuged at $1600 \mathrm{x} \mathrm{g}$ $\left(10 \mathrm{~min}\right.$ at $\left.4{ }^{\circ} \mathrm{C}\right)$, followed by a second centrifugation at $3200 \times \mathrm{g}\left(15 \mathrm{~min}\right.$ at $\left.4{ }^{\circ} \mathrm{C}\right)$ of resulting supernatants. Only clear FF samples, without any visible trace of blood contamination (presence of red blood cells) were stored at $-80^{\circ} \mathrm{C}$ until analyses.

\section{Electrophoresis of follicular-fluid proteins}

Optimal isolation of frozen-thawed equine FF proteins was tested through various equine FF:Acetone:Trichloroacetic Acid (TCA) mixture ratios (5:4:1, 1:4:0, and 1.7:3.3:0). Mixtures were incubated (overnight, $-20^{\circ} \mathrm{C}$ ), centrifuged $\left(9500 \mathrm{~g}, 10 \mathrm{~min}, 4^{\circ} \mathrm{C}\right)$, and supernatants were discarded. Cold acetone $\left(1 \mathrm{ml}\right.$, kept at $\left.-20^{\circ} \mathrm{C}\right)$ was added to each pellet and sample mixtures were vortexed (20 min), centrifuged $\left(9500 \mathrm{~g}, 10 \mathrm{~min}, 4^{\circ} \mathrm{C}\right.$ ), and resulting supernatants (acetone) were discarded. After three repetitions, pellets were dried under the fume hood and 
resuspended in the nanopure water. All protein samples were subjected to albumin depletion according to the manufacturer's instruction (ProteoExtract Albumin removal kit; Calbiochem EMD Biosciences, Darmstadt, Germany). Depleted protein samples were mixed with acetone in a 1:4 ratio ( $v / \mathrm{v}$ - FF:Acetone), precipitated overnight at $4{ }^{\circ} \mathrm{C}$, and washed twice with acetone by successive centrifugations $\left(9500 \mathrm{~g}, 10 \mathrm{~min}, 4^{\circ} \mathrm{C}\right)$. Final protein samples were quantified (NanoDrop spectrophotometer; Thermo Scientific, Grand Island, NY, USA) and aliquots of each sample were mixed with sample buffer and loaded into wells of a $4-12 \%$ sodium dodecyl sulfate polyacrylamide gel electrophoresis (SDS-PAGE). Gels were run as previously described [31], followed by staining with Coomassie blue R-250 reagent to visualize the protein bands.

\section{Liquid chromatography-mass spectrometry (LC-MS) analysis of follicular-fluid proteins}

Extracted FF proteins of each mare were determined (NanoDrop spectrophotometer, ThermoFisher Scientific) and equal amounts of proteins of two to four mares were pooled for each season (SAN, SOV, SUM, and FOV). For proteomic analyses, three independent pools $(100 \mu \mathrm{g}$ protein each) were constituted for each season. Pooled samples were precipitated overnight with 100\% acetone (1:5 ratio), washed two times with $100 \%$ acetone, air-dried, and stored at $-20^{\circ} \mathrm{C}$. Prior to in-solution digestion, protein precipitates were dissolved in $100 \mu \mathrm{l}$ of $100 \mathrm{mM}$ ammonium/5\% acetonitrile, reduced with $1 / 10$ volume of $100 \mathrm{mM}$ dithiothreitol (DTT) for $15 \mathrm{~min}$ at $65^{\circ} \mathrm{C}$, and alkylated with $1 / 10$ volume of $10 \mathrm{mM}$ iodoacetamide (IAA) for $30 \mathrm{~min}$ at room temperature in dark. Digestion was carried out with Trypsin/Lys-C Mix (Promega, Madison, WI) at $37^{\circ} \mathrm{C}$ overnight. Samples were freeze-dried and protein tryptic digest was resuspended in $0.1 \%(\mathrm{v} / \mathrm{v})$ formic acid, $2.0 \%(\mathrm{v} / \mathrm{v})$ acetonitrile. Aliquots of peptides representing two micrograms of protein were subjected to LC-MS analysis as described previously [32]. Briefly, peptides were separated using Ultimate 3000 HPLC system and reversed phase C18, $75 \mu \mathrm{m} \times 150 \mathrm{~mm}$ column (both Thermo Fisher Scientific), via $170 \mathrm{~min}$ long, nonlinear, constant flow $(0.3 \mu \mathrm{l} /$ $\mathrm{ml}$ ) gradient of acetonitrile (in $0.1 \%$ formic acid) as follows: $2-55 \%$ for $125 \mathrm{~min}, 95 \%$ for $15 \mathrm{~min}, 2 \%$ for $30 \mathrm{~min}$. Raw mass spectral data were collected by LTQ-Orbitrap Velos mass spectrometer (Thermo Fisher Scientific) working in the result dependent acquisition (RDA) mode of 18 scan events: one MS scan (m/z range: 300-1700) followed by 17 MSMS scans for the 17 most intense ions detected in MS scan, with dynamics exclusion allowed.

\section{Protein identification and bioinformatics analyses}

The raw files were searched using the SEQUEST algorithm of the Proteome Discoverer 1.1.0 software (Thermo
Fisher Scientific) as described previously [33]. Variable modifications were considered as follows: cysteine carbamidomethylation $(+57.021)$, methionine oxidation (+15.995), methionine dioxidation $(+31.990)$. The spectral data were matched against target and decoy databases to allow for calculation of false discovery rates (FDR). The NCBI (www.ncbi.nlm.nih.gov) Equus caballus taxonomy referenced protein database (36,108 entries as of August 2017) served as the target database, while its reversed copy (created automatically by the software) served as a decoy database. The search results were filtered by FDR $<1 \%$ for high-confidence protein identification. Proteins were functionally annotated (Gene ontology or GO, Enrichment, KEGG pathway, and protein-protein interactions) using the online tools of Agbase (http://agbase.arizona.edu/), DAVID (Database for Annotation, Visualization and Integrated Discovery; DAVID Bioinformatics Resources 6.8; https://david.ncifcrf.gov/home.jsp), and STRING (https:// string-db.org/cgi/input.pl?sessionId=LyvanBxDO3QN\&input_page_show_search=on) using the default settings.

\section{Results \\ Sample preparation prior to proteomic analysis}

The protein concentrations of pure FF derived from all seasons (SAN, SOV, SUM, and FOV) averaged $39.2 \pm$ $0.4,38 \pm 0.3,38.3 \pm 0.4$, and $39 \pm 0.4 \mu \mathrm{g} / \mu \mathrm{l}$, respectively. The use of pure FF samples $(33.2 \pm 0.4 \mu \mathrm{g} / \mu \mathrm{l})$ for protein precipitation tests (in 5:4:1, 1.7:3.3:0, and 1:4:0 solvent ratios) resulted in decreased protein concentrations (5.8 $\pm 0.1,7.9 \pm 0.2$, and $22.8 \pm 0.4 \mu \mathrm{g} / \mu \mathrm{l}$, respectively), while the additional albumin depletion procedure led to lesser protein concentrations in all tested FF groups $(0.1 \pm 0.01$, $0.14 \pm 0.01$, and $0.41 \pm 0.02 \mu \mathrm{g} / \mu \mathrm{l}$ for $5: 4: 1,1.7: 3.3: 0$, and 1:4:0 solvent ratios, respectively). Representative electrophoresis gels of both precipitated (Fig. 1a) and precipitated/depleted proteins (Fig. 1b) indicate comparable protein profiles across samples. Although the depletion of pure FF samples $(33.2 \pm 0.4 \mu \mathrm{g} / \mu \mathrm{l})$ produced lower protein concentrations $(0.59 \pm 0.2 \mu \mathrm{g} / \mu \mathrm{l})$, the recovery rate and gel electrophoresis protein profiles were satisfactory for further proteomic analysis.

\section{Total proteins identified}

All identified proteins are summarized (Table 1). The totals of $63,72,69$, and 78 proteins were identified with high confidence (FDR $<1 \%$ ) in SAN, SOV, SUM, and FOV samples, respectively. Approximately $87 \%$ of proteins were annotated with the NCBI-non redundant database, and 13\% with ENSEMBL. The Venn diagram (http://bioinformatics.psb.ugent.be/webtools/Venn/) indicates 52 proteins shared across all seasons, 25 proteins detected in two or three different seasons, and 13 unique proteins identified in a specific season (one for SAN, three for SOV, three for SUM, and six for FOV; Fig. 2). 


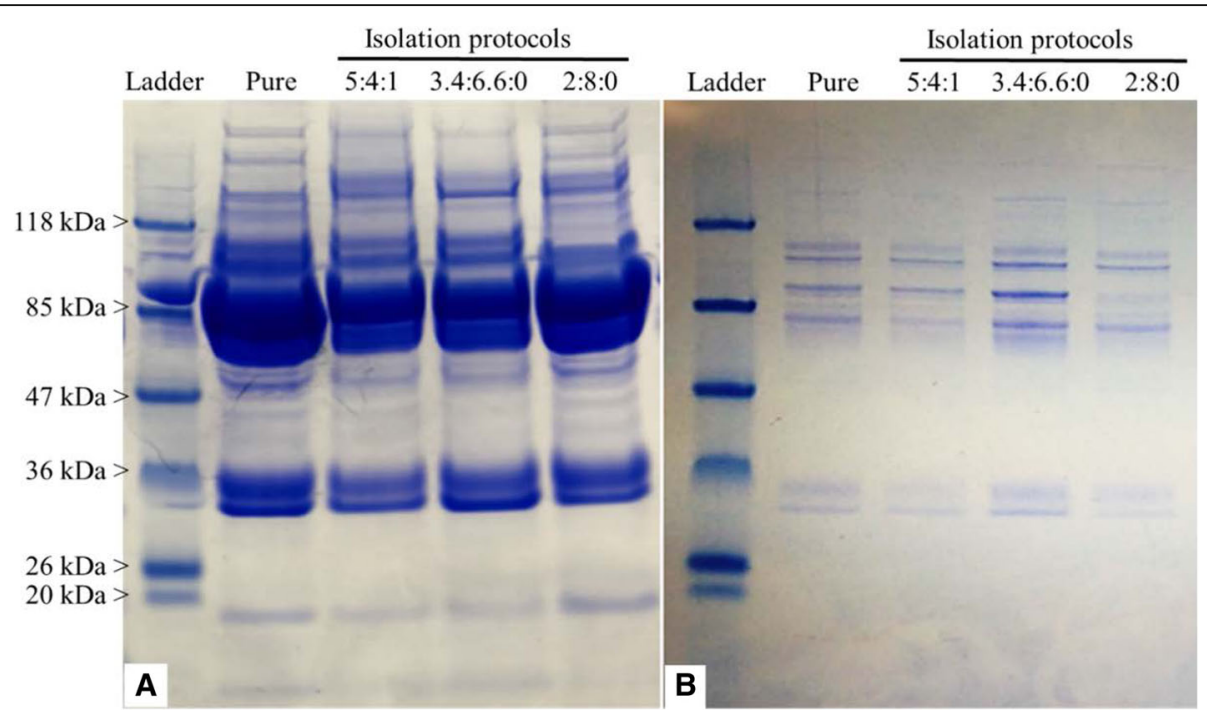

Fig. 1 Follicular fluid (FF) protein isolation through combined precipitation and depletion approach. Representative gel electrophoresis of equine FF submitted to four different Acetone-TCA-based protein precipitation protocols (a), followed by albumin depletion (b) are shown. Gels were stained with Coomassie blue to visualize the protein bands, showing decreased protein amounts following both precipitation and depletion. Utilization of pure FF revealed higher protein recovery following depletion. Extraction protocols (5:4:1, 3.4:6.6:0, and 2:8:0) corresponded to FF:Acetone:TCA, respectively

Overall, a total of 90 proteins were detected in the FF samples across all seasons. Proteins found in each intersection of the Venn diagram are listed in a textual output (Table 2), and all seasonal proteome datasets with full protein annotations are provided as supplementary data (Additional file 1: Table S1).

\section{Functional classification, protein enrichment, and pathways analyses}

For functional classification, GO annotation was available for 88.5 to $91.7 \%$ of identified proteins across the season datasets. Proteins were classified into three GO categories as cellular components (CC), molecular functions (MF), and biological processes (BP). Regardless of season, proteins were distributed within 9-10, 12, and $20 \mathrm{GO}$ terms associated with CC, MF, and BP, respectively. The functional categorization of shared proteins and the observed quantitative variations in GO terms constituting each functional category are shown (Fig. 3).

Irrespective of the season, GO terms associated with extracellular components (space, region, cell surface, membrane, and proteinaceous) represented approximately $54 \%$ of the total annotations within the CC category (Table 3). These specific GO terms were $6 \mathrm{x}$ to $9 \mathrm{x}$ enriched $\left(P<10^{-5}, \mathrm{FDR}<0.01\right)$. Other GO names such as "blood microparticle" and "fibrinogen complex" were significantly enriched ( $>104 \mathrm{x} ; \mathrm{P}<10^{-4}$, FDR $\left.<0.01\right)$ in our datasets. Similarly, the GO terms associated with binding (binding, protein, and nucleic acid) were highly represented ( 49\%) within the MF category (Table 4$)$, and only the "serine-type endopeptidase inhibitor activity" GO term revealed significant enrichment across all seasons (46-63x; $P<10^{-16}$, FDR $\left.<0.01\right)$. Nonetheless, several GO terms associated with binding (e.g., heparin, cholesterol, phosphatidylcholine, and copper ion) and enzymatic activity (e.g., cholesterol transporter, phosphatidylcholine-sterol O-acyltransferase activator, structural molecule, cysteine-type endopeptidase inhibitor) were significantly enriched $(>6 \mathrm{x} ; P<0.05)$, but with higher FDR $(>0.01)$. As for the BP category across seasons, approximately $70,8,5$, and $4 \%$ of total annotations were respectively associated with

Table 1 Seasonal variation of equine follicular fluid proteome

\begin{tabular}{|c|c|c|c|c|}
\hline \multirow[t]{3}{*}{ Reproductive seasons } & \multicolumn{4}{|c|}{ Number of detected proteins } \\
\hline & \multirow[t]{2}{*}{$\mathrm{N}$} & \multicolumn{2}{|c|}{ NCBI annotated (\%) } & \multirow[t]{2}{*}{ ENSEMBL annotated (\%) } \\
\hline & & Partially & Fully & \\
\hline Spring anovulatory (SAN) & 63 & $42(66.7)$ & $12(19.0)$ & $9(14.3)$ \\
\hline Spring ovulatory (SOV) & 72 & $48(66.7)$ & $14(19.4)$ & $10(13.9)$ \\
\hline Summer (SUM) & 69 & $47(68.1)$ & $13(18.8)$ & $9(13.0)$ \\
\hline Fall ovulatory (FOV) & 78 & $49(62.8)$ & $18(23.1)$ & $11(14.1)$ \\
\hline
\end{tabular}




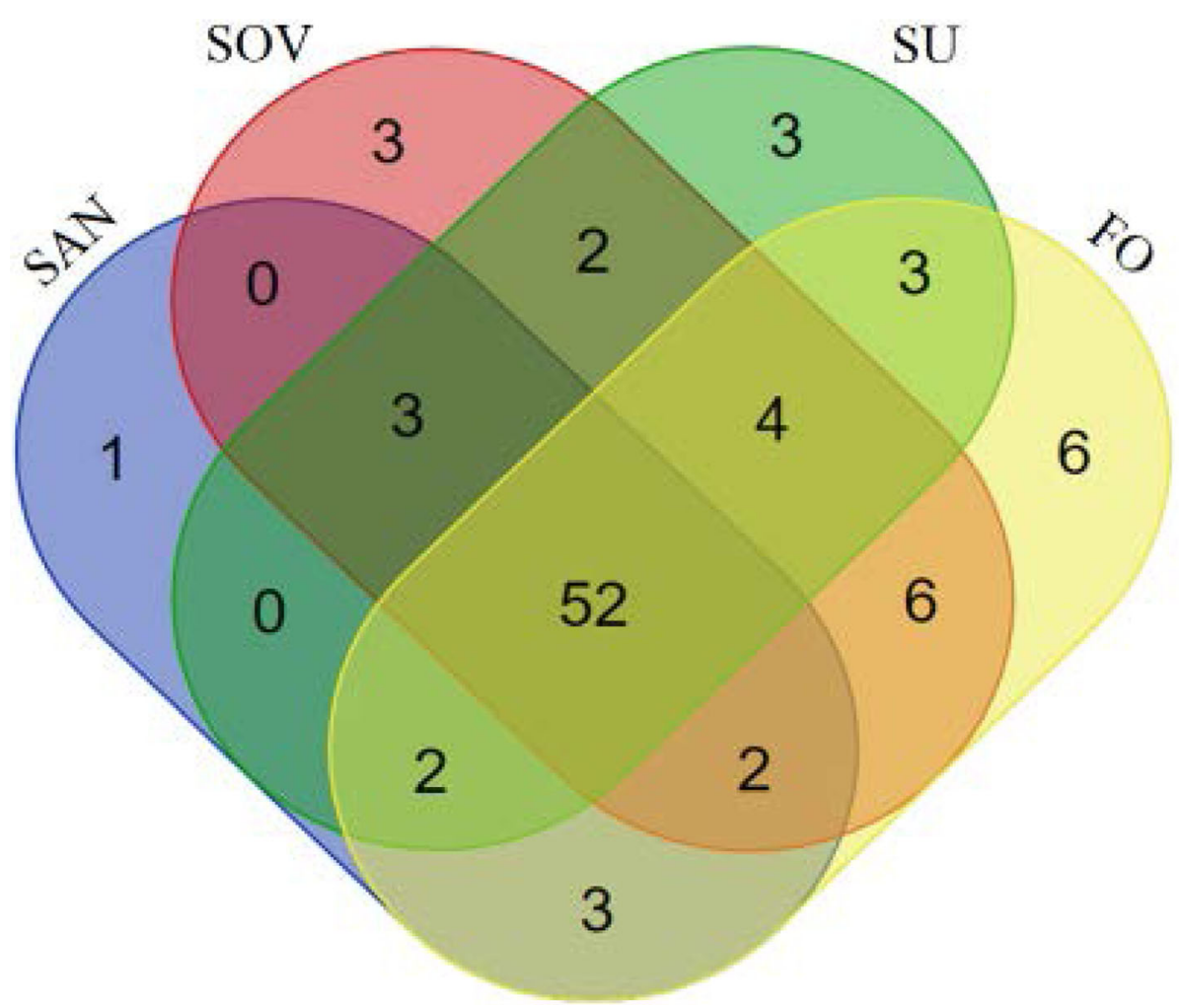

Fig. 2 Venn diagram representation of proteins identified in equine follicular fluid across seasons. Spring anovulatory (SAN), spring ovulatory (SOV), summer (SUM or SU) and fall ovulatory (FOV or FO) seasons

Table 2 Equine follicular fluid proteins distribution across four reproductive seasons

\begin{tabular}{|c|c|c|}
\hline Reproductive seasons & $\begin{array}{l}\text { Number of unique } \\
\text { proteins }\end{array}$ & NCBI/ENSEMBL accession numbers \\
\hline SAN/SOV/SUM/FOV & 52 & $\begin{array}{l}\text { ENSECAP00000007499 XP_001498388 XP_001489154 XP_003365492 XP_001504386 XP_014588282 } \\
\text { XP_001502426 NP_001075422 XP_014596181 XP_003363176 XP_001500552 NP_001075379 XP_ } \\
005605480 \text { XP_005601929 XP_005602671 XP_001499389 XP_005611649 XP_005612174 NP_001304178 } \\
\text { ENSECAP00000010483 XP_014594947 XP_001488384 XP_014593946 XP_005600608 XP_001497860 } \\
\text { NP_001075415 XP_001916967 XP_001492943 NP_001075972 XP_001499173 XP_001502503 XP_- } \\
001496277 \text { XP_001492602 ENSECAP00000017379 NP_001075413 ENSECAP00000012479 } \\
\text { ENSECAP00000014609 ENSECAP00000012399 XP_001915589 XP_001489797 XP_001503846 XP_- } \\
\text { 003364583 XP_001490892 ENSECAP00000013972 XP_001914833 XP_014585351 XP_001492576 } \\
\text { XP_001489400 XP_001495232 XP_014593950 ENSECAP00000009723 XP_001504173 }\end{array}$ \\
\hline SAN/SOV/SUM & 3 & NP_001333128 XP_001488181 XP_001488234 \\
\hline SAN/SOV/FOV & 2 & NP_001075419 NP_001093235 \\
\hline SAN/SUM/FOV & 2 & XP_005607860 XP_014593981 \\
\hline SOV/SUM/FOV & 4 & NSECAP00000018005 NP_001137426 NP_001075389 XP_001501882 \\
\hline SAN/FOV & 3 & NP_001333146 NP_001333133 ENSECAP00000017139 \\
\hline SOV/SUM & 2 & NP_001333066 XP_005605484 \\
\hline SOV/FOV & 6 & XP_014591249 NP_001075249 XP_005601424 XP_001491754 XP_001493453 NP_001075420 \\
\hline SUM/FOV & 3 & NP_001075378 XP_001496318 NP_001108005 \\
\hline SAN & 1 & NP_001333005 \\
\hline SOV & 3 & XP_001504484 XP_001504447 ENSECAP00000013036 \\
\hline SUM & 3 & XP_005599640 XP_005605481 NP_001271464 XP_001917127 \\
\hline FOV & 6 & ENSECAP00000012950 NP_001157490 XP_001499312 NP_001108630 XP_001492582 XP_014592983 \\
\hline
\end{tabular}


A

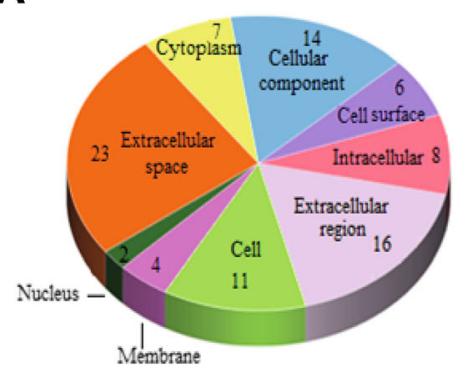

Molecular function

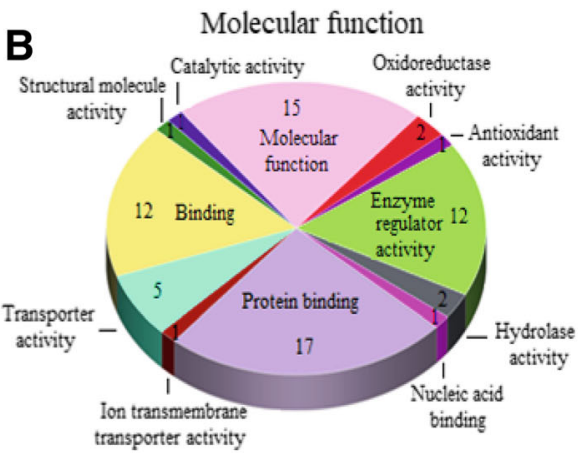

\section{Biological process}

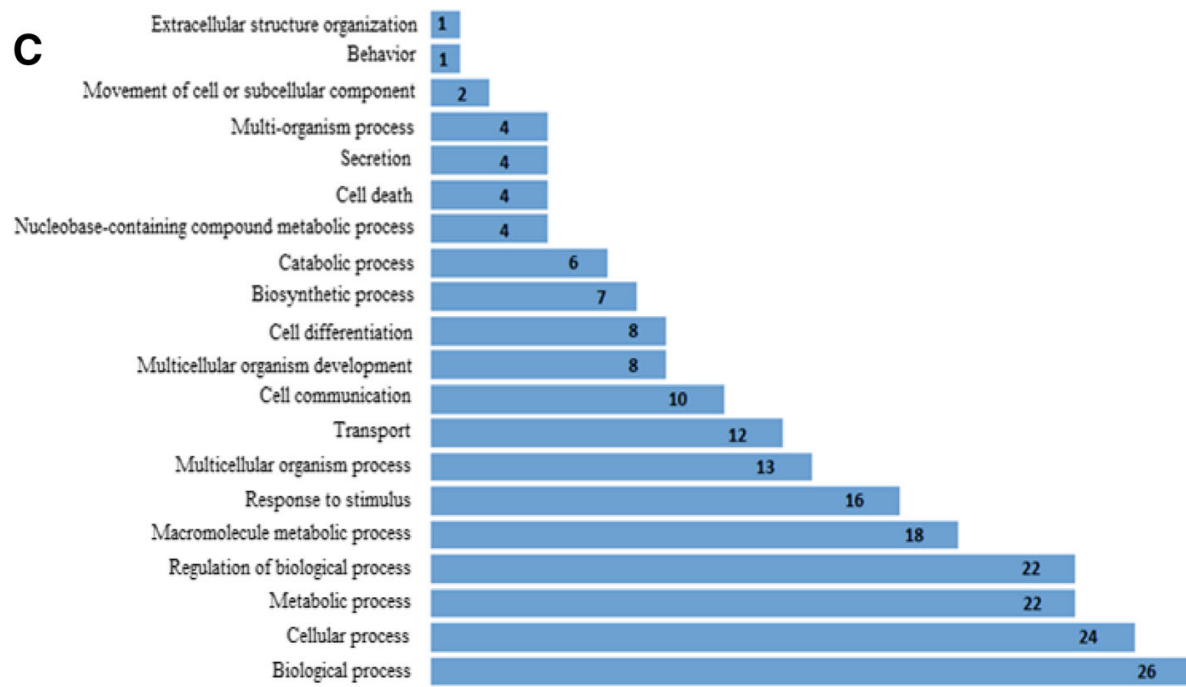

Fig. 3 Functional categorization of proteins shared across all seasons. Distribution of total protein per gene ontology (GO) terms in the Cellular component (a), Molecular function (b), and Biological process (c) categories

Table 3 Cellular component of equine follicular fluid proteins across four different reproductive seasons

\begin{tabular}{|c|c|c|c|c|c|}
\hline \multirow[t]{2}{*}{ GO terms / GO names } & \multicolumn{4}{|c|}{ Reproductive seasons } & \multirow{2}{*}{$\begin{array}{l}\text { Shared } \\
\text { proteins } \\
\mathrm{n}(\%) \\
\end{array}$} \\
\hline & $\begin{array}{l}\text { SAN } \\
\text { n (\%) }\end{array}$ & $\begin{array}{l}\text { SOV } \\
\text { n (\%) }\end{array}$ & $\begin{array}{l}\text { SUM } \\
\text { n (\%) }\end{array}$ & $\begin{array}{l}\text { FOV } \\
\text { n (\%) }\end{array}$ & \\
\hline GO:0005615 / Extracellular space & $25(24.0)$ & $29(23.8)$ & $29(26.9)$ & $32(25.4)$ & $23(25.3)$ \\
\hline GO:0005575 / Cellular component & $17(16.3)$ & $21(17.2)$ & $18(16.7)$ & $22(17.5)$ & $14(15.4)$ \\
\hline GO:0005576 / Extracellular region & $17(16.3)$ & 19 (15.6) & 19 (17.6) & $21(16.7)$ & $16(17.6)$ \\
\hline GO:0005623 / Cell & $14(13.5)$ & $17(13.9)$ & $13(12.0)$ & $16(12.7)$ & $11(12.1)$ \\
\hline GO:0005622 / Intracellular & $9(8.7)$ & $12(9.8)$ & $10(9.3)$ & $11(8.7)$ & $8(8.8)$ \\
\hline GO:0005737 / Cytoplasm & $7(6.7)$ & $8(6.6)$ & $7(6.5)$ & $8(6.3)$ & $7(7.7)$ \\
\hline GO:0009986 / Cell surface & $6(5.8)$ & $6(4.9)$ & $6(5.6)$ & $6(4.8)$ & $6(6.6)$ \\
\hline GO:0016020 / Membrane & $6(5.8)$ & $6(4.9)$ & $4(3.7)$ & $6(4.8)$ & $4(4.4)$ \\
\hline GO:0005634 / Nucleus & $3(2.9)$ & $3(2.5)$ & $2(1.9)$ & $3(2.4)$ & $2(2.2)$ \\
\hline GO:0005578 / Proteinaceous extracellular matrix & - & $1(0.8)$ & - & $1(0.8)$ & - \\
\hline Total annotations & $104(100)$ & $122(100)$ & $108(100)$ & $126(100)$ & $91(100)$ \\
\hline
\end{tabular}

SAN spring anovulatory, SOV spring ovulatory, SUM summer, FOV fall ovulatory 
Table 4 Molecular function of equine follicular fluid proteins across four different reproductive seasons

\begin{tabular}{|c|c|c|c|c|c|}
\hline \multirow[t]{2}{*}{ GO terms / GO names } & \multicolumn{4}{|c|}{ Reproductive seasons } & \multirow{2}{*}{$\begin{array}{l}\text { Shared } \\
\text { proteins } \\
\mathrm{n}(\%)\end{array}$} \\
\hline & $\begin{array}{l}\text { SAN } \\
\text { n (\%) }\end{array}$ & $\begin{array}{l}\text { SOV } \\
\text { n (\%) }\end{array}$ & $\begin{array}{l}\text { SUM } \\
\text { n (\%) }\end{array}$ & $\begin{array}{l}\text { FOV } \\
\text { n (\%) }\end{array}$ & \\
\hline GO:0005488 / Binding & $22(26.2)$ & $25(27.2)$ & $25(27.2)$ & $29(27.9)$ & $21(27.6)$ \\
\hline GO:0005515 / Protein binding & $18(19.6)$ & $18(19.6)$ & $19(20.7)$ & $20(19.2)$ & $17(19.0)$ \\
\hline GO:0003674 / Molecular function & $16(19.6)$ & $16(17.4)$ & $17(18.5)$ & $20(19.2)$ & $15(18.1)$ \\
\hline GO:0030234 / Enzyme regulator activity & $12(14.3)$ & $12(13.0)$ & $13(14.1)$ & $13(12.5)$ & $12(11.2)$ \\
\hline GO:0005215 / Transporter activity & $5(6.0)$ & $6(6.5)$ & $5(5.4)$ & $6(5.8)$ & $5(5.2)$ \\
\hline GO:0016787 / Hydrolase activity & $2(2.4)$ & $4(4.3)$ & $2(2.2)$ & $4(3.8)$ & $2(3.4)$ \\
\hline GO:0005198 / Structural molecule activity & $2(2.4)$ & $4(4.3)$ & $3(3.3)$ & $3(2.9)$ & $1(4.3)$ \\
\hline GO:0016491 / Oxidoreductase activity & $2(2.4)$ & $2(2.2)$ & $3(3.3)$ & $3(2.9)$ & $2(1.7)$ \\
\hline GO:0003676 / Nucleic acid binding & $2(2.4)$ & $1(1.1)$ & $2(2.2)$ & $2(1.9)$ & $1(3.4)$ \\
\hline GO:0003824 / Catalytic activity & $1(1.2)$ & $2(2.2)$ & $1(1.1)$ & $2(1.9)$ & $1(2.6)$ \\
\hline GO:0015075 / lon transmembrane transporter activity & $1(1.2)$ & $1(1.1)$ & $1(1.1)$ & $1(1.0)$ & $1(0.9)$ \\
\hline GO:0016209 / Antioxidant activity & $1(1.2)$ & $1(1.1)$ & $1(1.1)$ & $1(1.0)$ & $1(0.9)$ \\
\hline Total annotations & $84(100)$ & $92(100)$ & $92(100)$ & $104(100)$ & $79(100)$ \\
\hline
\end{tabular}

SAN spring anovulatory, SOV spring ovulatory, SUM summer, FOV fall ovulatory

"processes", "response to stimulus", "transport", and "cell communication" (Table 5). Meanwhile, the "acute-phase response", "fibrinolysis", and "positive regulation of cholesterol esterification" GO terms were significantly enriched in all seasonal samples ( $>62 x ; P<10^{-3}$, FDR $<0.01$ ), and the "blood coagulation" GO term was substantially enriched in the SUM samples only $\left(36 \mathrm{x} ; \mathrm{P}<10^{-3} ; \mathrm{FDR}<0.01\right)$. Finally, the "complement and coagulation cascades" KEGG pathway was significantly enriched $\left(50-54 \mathrm{x} ; \mathrm{P}<10^{-3}\right.$; FDR $<0.01$ ), regardless of the reproductive season.

\section{Comparison between reproductive seasons}

1Qualitative and quantitative differences in GO terms constituting each functional category were found across seasons (Tables 3-5). GO terms associated with "extracellular space" (in CC category) and "protein binding" (in MF category) increased in SUM compared to other seasonal groups. In contrast, GO terms associated with "membrane" and "nucleus" (in CC category), "transporter activity" (in MF category), and "response to stimulus" (in BP category) were decreased in SUM. Moreover, the proportions of annotations associated with "transporter activity" in MF and "response to stimulus" in BP were higher in SOV and FOV, respectively, compared to other seasons. Finally, GO terms associated with "intracellular" (in CC category), "binding", "hydrolase activity", and "structural molecule activity" (in MF category), and "biological process", and "multicellular organism process" (in BP category) were lower in SAN compared to SOV.

\section{Protein-protein interaction (PPI) network analyses}

The PPI analysis was performed for each season, including the shared protein dataset. For each dataset, three major PPI K-means clustering were obtained with high confidence interaction score $(>0.7)$ and significant PPI enrichment $\left(P<10^{-16}\right)$. A representative PPI network generated from shared dataset is shown (Fig. 4). The three main clusters (circles) and related key proteins having higher numbers of interactions are indicated. Cluster 1 (green in Fig. 4) revealed F2 protein (or prothrombin) with the greatest interactions in $\operatorname{SAN}(n=12)$, SOV $(n=14)$, FOV $(n=13)$, and shared $(n=12)$ protein datasets, while the combination of F2 $(n=13)$ with PLG (plasminogen, $n=11$ ) appeared as the main players in the SUM dataset. In cluster 2 (blue in Fig. 4), plasminogen had the highest number of interactions in SAN and shared datasets $(n=10)$, while the combination of both plasminogen $(\mathrm{n}=10)$ and ENSECAG00000000339 (complement C3) with four and five interactions may have important roles during SOV and FOV seasons, respectively. Contrarily in the SUM dataset, the F12 (coagulation factor XII) protein appeared as the main player with 12 interactions. Finally, the cluster 3 (red in Fig. 4) revealed APOA1 (apolipoprotein 1) protein as the key player in all seasons.

\section{Discussion}

The current study uses a gel-free technique to provide unique proteomic datasets of equine FF of dominant growing follicles $(30-34 \mathrm{~mm}$ in diameter) during the SAN, SOV, SUM, and FOV seasons. The existence of seasonal proteins in a similar follicle class, reported 
Table 5 Biological process of equine follicular fluid proteins across four different reproductive seasons

\begin{tabular}{|c|c|c|c|c|c|}
\hline \multirow[t]{2}{*}{ GO terms / GO names } & \multicolumn{4}{|c|}{ Reproductive seasons } & \multirow{2}{*}{$\begin{array}{l}\text { Shared } \\
\text { proteins } \\
\mathrm{n}(\%)\end{array}$} \\
\hline & $\begin{array}{l}\text { SAN } \\
\text { n (\%) }\end{array}$ & $\begin{array}{l}\text { SOV } \\
\text { n (\%) }\end{array}$ & $\begin{array}{l}\text { SUM } \\
\text { n (\%) }\end{array}$ & $\begin{array}{l}\text { FOV } \\
\text { n (\%) }\end{array}$ & \\
\hline GO:0008150 / Biological process & $31(13.2)$ & $35(13.8)$ & $32(12.7)$ & $40(13.7)$ & $26(12.3)$ \\
\hline GO:0009987 / Cellular process & $26(11.1)$ & $29(11.5)$ & $28(11.2)$ & $32(11.0)$ & $24(11.3)$ \\
\hline GO:0050789 / Regulation of biological process & $25(10.7)$ & $28(11.1)$ & $27(10.8)$ & $30(10.3)$ & $22(10.4)$ \\
\hline GO:0008152 / Metabolic process & $24(10.3)$ & $25(9.9)$ & $26(10.4)$ & $30(10.3)$ & $22(10.4)$ \\
\hline GO:0043170 / Macromolecule metabolic process & $20(8.5)$ & $20(7.9)$ & $20(8.0)$ & $24(8.2)$ & $18(8.5)$ \\
\hline GO:0050896 / Response to stimulus & $19(8.1)$ & $20(7.9)$ & $19(7.6)$ & $25(8.6)$ & $16(7.5)$ \\
\hline GO:0032501 / Multicellular organism process & $14(6.0)$ & $17(6.7)$ & $16(6.4)$ & $18(6.2)$ & $13(6.1)$ \\
\hline GO:0006810 / Transport & $12(5.1)$ & $14(5.5)$ & $13(5.2)$ & $16(5.5)$ & $12(5.7)$ \\
\hline GO:0007154 / Cell communication & $10(4.3)$ & $10(4.0)$ & $11(4.4)$ & $11(3.8)$ & $10(4.7)$ \\
\hline GO:0007275 / Multicellular organism development & $9(3.8)$ & $10(4.0)$ & $10(4.0)$ & $11(3.8)$ & $8(3.8)$ \\
\hline GO:0030154 / Cell differentiation & $9(3.8)$ & $9(3.6)$ & $10(4.0)$ & $11(3.8)$ & $8(2.8)$ \\
\hline GO:0009058 / Biosynthetic process & $8(3.4)$ & $7(2.8)$ & $8(3.2)$ & $9(3.1)$ & $7(3.3)$ \\
\hline GO:0009056 / Catabolic process & $6(2.6)$ & $7(2.8)$ & $6(2.4)$ & $8(2.7)$ & $6(2.8)$ \\
\hline GO:0006139 / Nucleobase-containing compound metabolic process & $5(2.1)$ & $4(1.6)$ & $5(2.0)$ & $6(2.1)$ & $4(1.9)$ \\
\hline GO:0008219 / Cell Death & $4(1.7)$ & $4(1.6)$ & $5(2.0)$ & $5(1.7)$ & $4(1.9)$ \\
\hline GO:0046903 / Secretion & $4(1.7)$ & $4(1.6)$ & $5(2.0)$ & $5(1.7)$ & $4(1.9)$ \\
\hline GO:0051704 / Multi-organism process & $4(1.7)$ & $4(1.6)$ & $6(2.4)$ & $5(1.7)$ & $4(1.9)$ \\
\hline GO:0006928 / Movement of cell or subcellular component & $2(0.9)$ & $3(1.2)$ & $2(0.8)$ & $2(0.7)$ & $2(0.9)$ \\
\hline GO:0043062 / Extracellular structure organization & $1(0.4)$ & $1(0.4)$ & $1(0.4)$ & $2(0.7)$ & $1(0.5)$ \\
\hline GO:0007610 / Behavior & $1(0.4)$ & $1(0.4)$ & $1(0.4)$ & $1(0.3)$ & $1(0.5)$ \\
\hline Total annotations & $234(100)$ & $253(100)$ & $251(100)$ & $291(100)$ & $212(100)$ \\
\hline
\end{tabular}

SAN spring anovulatory, SOV spring ovulatory, SUM summer, FOV fall ovulatory

herein for the first time, suggests potential critical roles of FF proteins during the folliculogenesis and maybe oogenesis in the equine species. Likewise, various biological functions, protein enrichment, and protein interaction networks are reported to have been influenced by the seasonal variations.

\section{Follicular fluid proteins isolation}

Combination of procedures, such as protein precipitation and depletion of high-abundant proteins, are routinely used to enhance the quality of starting samples for proteomic analyses [28, 34, 35]. In this study, all tested precipitation protocols (FF:Acetone:TCA ratio of 5:4:1, 1:4:0, and 1.7:3.3:0) resulted in expected lower protein concentrations (30 to $82 \%$ losses) that were exacerbated by a further depletion of high-abundance serum protein (about 99\% losses). Interestingly, the electrophoretic profiles of protein samples were generally comparable, regardless of the procedure. Crude equine FF samples maintained the highest protein concentrations following depletion, with only $30 \%$ loss, from $33.2 \pm 0.4 \mu \mathrm{g} / \mu \mathrm{l}$ to $22.8 \pm 0.4 \mu \mathrm{g} / \mu \mathrm{l}$. Thereafter, the 1:4:0 precipitation ratio appeared the most suitable with lesser protein loss, which was consistent with a previous report Santa et al. [36].

\section{Proteome description}

The gel-free LC-MS proteomics has been successfully used in previous studies of FF of stock animals [21, 23, 26]. The present study applied strict filters (FDR $<1 \%$, and the minimum of two unique peptides per protein) to obtain proteins with high confidence identification, which may explain the slightly lower number of detected proteins (90 vs. 113) when compared to available FF mare proteome [28]. In addition, the proteome dataset of the current study contains fewer proteins in comparison to other monovular species such as humans (158 to 1079; [24, 37-40]), and dairy cattle (113 to 219; [15, 21]). Nonetheless, the aforementioned proteomic studies were generally performed with FF samples obtained from follicles of different sizes and unknown physiological statuses (i.e., growing and regressing follicles), under different technical approaches (e.g., gel-based or gel-free) and protein call stringencies (e.g., false discovery rate and peptides). The full annotation (87\% with NCBI and 13\% with ENSEMBL) of all detected proteins 


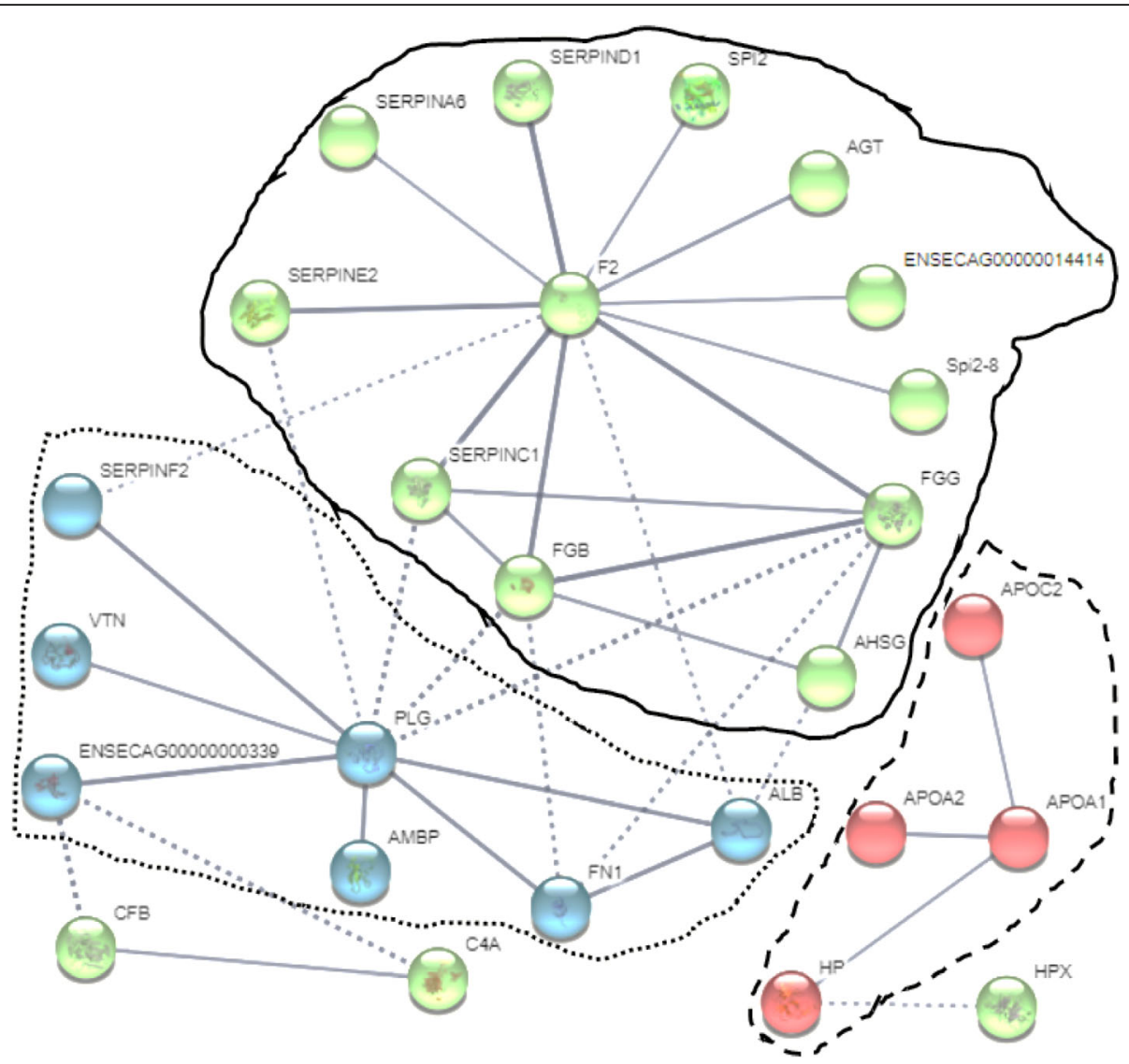

Fig. 4 Protein-to-Protein Interaction network of proteins shared across all seasons

offers opportunities for in-depth investigations, such as the dynamic composition of the equine $\mathrm{FF}$ proteome and the relationship with oocyte quality. To the best of our knowledge, this is the first study providing essential clues of the FF proteome variations to enable a further understanding of the impact of different seasons on fertility of the mare, and maybe of other livestock.

\section{Proteins specifics to seasons}

Among the 90 proteins, a core set of 52 was detected across all seasons. It is expected that these proteins may have essential roles during folliculogenesis [39] and oogenesis [2] processes, as previously reported in humans. In contrast, the examined seasons were characterized by subsets of proteins that may serve as potential biomarkers of seasonal fertility in mares. For instance, the BPI (Bactericidal/Permeability-Increasing) fold-contain Family A member 2 (BPIFA2) precursor was found only in SOV, SUM, and FOV (ovulatory seasons). The BPI is an endogenous antibiotic protein that belongs to the family of mammalian lipopolysaccharide (LPS)-binding and lipid transport protein. The BPIFA2 is known to have a role in the innate immune responses and was reported to inhibit the formation of biofilm by pathogenic gram-negative bacteria in the respiratory tract [41]. In this regard, although the function for BPI in FF is still unknown, the presence of BPIFA2 during the ovulatory seasons may be important to protect the female genital tract (e.g., oviduct). Also, few reports have found that BPI is expressed in the testis and epididymis of mice and appears to take part in the process of gamete interactions [42, 43].

In contrast, keratin-10 was detected in SAN samples only and may, therefore, be associated with the non-ovulatory seasons. Although keratin is considered a common contaminant in proteomic studies, the keratin-10 family member has been reported as a negative modulator of cell cycle progression throughout the Phospho-Inositol 3 kinase (PI3 kinase) signal transduction pathway [44]. Numerous studies have reported the participation of PI3 kinase in the follicle-stimulating hormone or progesterone-induced meiotic oocyte maturation in Xenopus $[45,46]$ and mouse $[47,48]$. In the present study, eight keratin-like family members were present in different intersections of the Venn diagram, and their specific roles in the acquisition of the oocyte developmental competence remain to be unfolded. 


\section{Functional analyses}

In this study, the interpretation of bioinformatics analyses focused only on proteins exhibiting thresholds of significance that were lower than $1 \%$ in both Benjamini-Hochberg and FDR analyses. About half of the protein annotations belonged to the Extracellular GO term, and only $10 \%$ of the total annotations were attributed to Intracellular localization, regardless of the proteome dataset. This distribution is expected, given the composition of the FF, known to contain secretions of follicle cells and blood plasma exudates. Thus, proteins attributed to Intracellular regions may be residues of the various catabolic processes and/or cell breakdown (apoptosis) of follicle cells (granulosa cells) that occur throughout the follicle growth $[39,49,50]$. Protein distributions within the present FF datasets are in agreement with previous reports in other species [24, 51, 52], but differ from the uniquely available report in horses [28], indicating $83 \%$ of protein annotations within the Extracellular region and 17\% Intracellular. This difference may be due to either the mare breeds (Welsh pony vs. Quarter horse in the current study) or their proteome dataset generated from the combination of distinct follicle physiological stages.

Regarding protein functions, approximately $49 \%$ of the total annotations belonged to binding (protein binding and nucleic acid binding GO terms), and 32\% corresponded to other cellular and molecular activities. This specific distribution is in agreement with previous studies in humans [24, 51], and reflects the participation of FF proteins in a variety of physiological functions associated with follicle and oocyte growth. In this study, several proteins belonging to the serine-type endopeptidase inhibitor activity, binding (heparin, cholesterol, and copper ion), and enzyme transporter (cholesterol) were significantly enriched across all seasons; those proteins have also been detected in other mono-ovulatory species $[28,52]$.

Proteins associated with inflammatory responses (immune system, coagulation, acute phase response signaling), a FF signature across studies and species such as humans [53], goats [52], cattle [21], and horses [28], were significantly enriched in our datasets. These proteins may participate in cascades of immune and coagulation formation (fibrin) /inhibition (anti-thrombin) responses having vital roles in follicle growth and oocyte transfer to the oviduct following ovulation. The anticoagulation function of the FF has been revealed to be essential during follicle growth and rupture [54]; moreover, in all of our datasets (SAN, SOV, SUM, and FOV), a significant enrichment in proteins associated with the coagulation cascade was noticed.

The functional categorization indicated a higher proportion of proteins associated with the "Extracellular space" GO name during the SUM season. The increase in FF protein content found in our study during the SUM season may have been due to an increase in ovarian vascularization/blood flow $[9,55,56]$, likely favoring the entry of additional plasma proteins into the follicle. Interestingly, the SAN dataset exhibited lower numbers of proteins associated with "Intracellular" (in CC); "Hydrolase activity", "Structural molecule activity", and "Binding" (in MF); and "Biological process" and "Multicellular organism process" (in BP) than that of the SOV dataset. These differences may lead to further understanding of the differences in FF environment of dominant anovulatory versus ovulatory follicles during the SAN and SOV seasons, respectively.

\section{Protein and pathway enrichments}

Proteins associated with the "complement and coagulation cascades" pathway were significantly enriched in all seasons: $25.4 \%$ in SAN, $23.6 \%$ SOV, 23.2\% SUM, and $25.6 \%$ FOV. Indeed, the complement system and inflammatory processes regulate follicle development and ovulation [57-59]. Numerous proteins are known to play essential roles during major events of the ovarian follicle [60]. These events involve a variety of proteolytic and metabolic processes that are mediated by several enzymes found in our datasets. Furthermore, the synthesis of some proteins may have been favored by the high number of protease inhibitors found in our study, such as fetuin- $B$, plasma protease $C 1$ inhibitor, protein Z-dependent protease inhibitor, alpha-1-antiproteinase 2, alpha-1-antichymotrypsin, GDN peptidase inhibitor 7, inter-alpha-trypsin inhibitor heavy chain $\mathrm{H} 1, \mathrm{H} 2$ and $\mathrm{H} 4$, and SERPIN for serine-protease inhibitors. Among them, the SERPIN, a superfamily of protease inhibitors [61], are involved in follicle development and may regulate the follicular extracellular matrix remodeling [22]. On the other hand, many other proteins were associated with coagulation cascades. The presence of proteins such as antithrombin-III, alpha macroglobulin, plasminogen, alpha-2-antiplasmin, and fibrinogen indicates their participation in the controlling, modeling, and regulation of the coagulation pathway leading to healthy follicle growth.

\section{Protein-protein interaction (PPI) networks}

The PPI network information is one of the major fields in systems biology allowing for complex network analyses [62]. The PPI permitted the consolidation of the "coagulation cascade" (Fig. 5) as a main signature of the equine FF, as seen in all datasets (SAN, SOV, SUM, FOV, and shared proteins) and previous reports in various species $[28,52,53]$. Clustering analyses allowed the prediction of the combination of F12 (coagulation factor XII), F2 (prothrombin), and PLG (plasminogen) as the signature of equine FF proteins during SUM, while the 


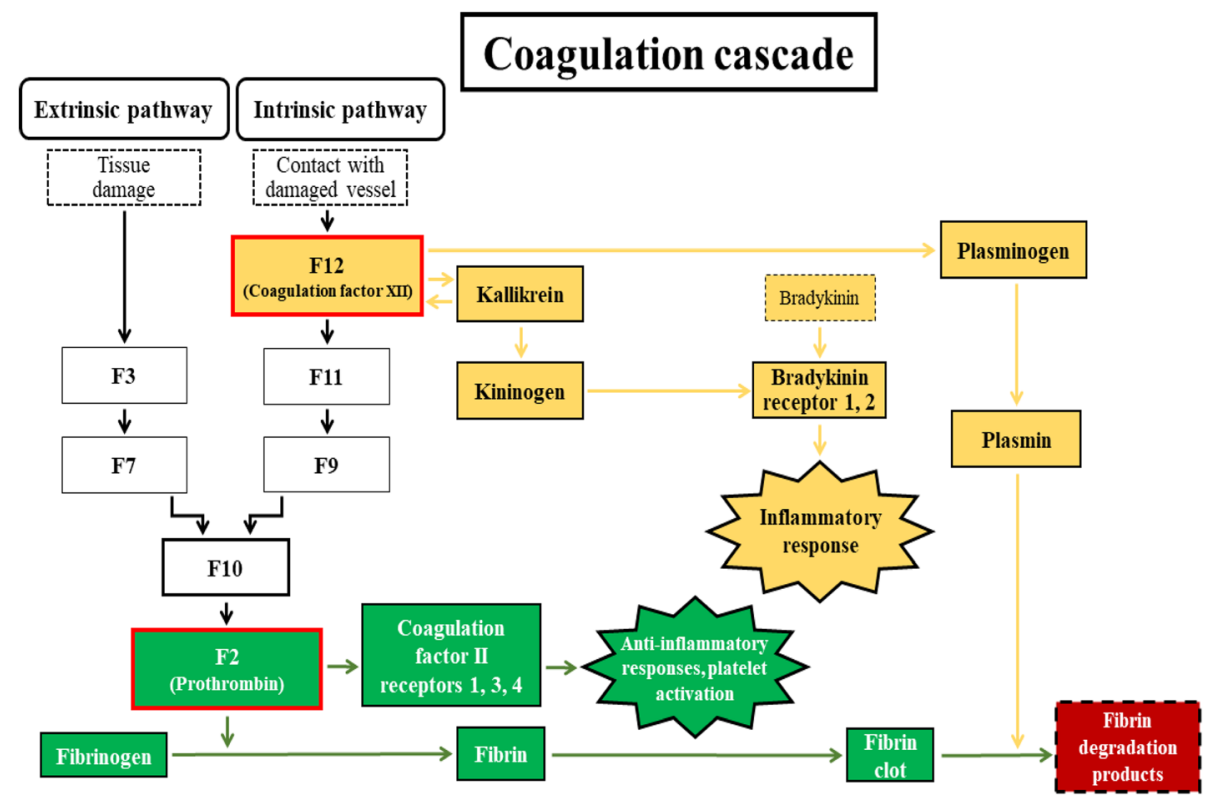

Fig. 5 Schematized "coagulation cascade" pathway derived from proteins shared across all seasons. Adapted from KEGG Pathway Database of "Coagulation and Complement Cascade" (map04610; http://www.genome.jp/kegg/pathway.html). This diagram shows the roles of the F12 protein (Coagulation factor XII; yellow color), in the intrinsic pathway and the F2 protein (Prothrombin; green color), in the extrinsic pathway of the cascade, leading to the "fibrin degradation products"

F2-PLG-ENSECAG00000000339 (complement C3) combination had higher interactions in both the SOV and FOV seasons. In contrast, both F2 and PLG were mainly found during the SAN season. These observations are significant given the functions of the implicated proteins.

Firstly, prothrombin or F2 is a glycoprotein and an essential component of the blood-clotting mechanism exerting effects through its mature form, thrombin, by interacting with specific receptors (or protease-activated receptors or ThRs) on the granulosa cell membrane [63, 64]. However, its contribution as an anti-inflammatory compound prone to induce hemorrhagic anovulatory follicles during the transitional reproductive seasons remains to be explored. Secondly, the coagulation factor XII or F12, however, is a pro-inflammatory protein interacting with prekallikrein to initiate a cascade of events leading to the release of bradykinin [65], which in turn increases the action of LH, contributes to follicular wall contraction [66], and favors ovulation [66-68]. These observations are supportive of the increased protein-protein interactions of the coagulation factor XII during SUM, having possible roles in the ovulation outcome in mares. Thirdly, the proteolytic factor plasminogen is capable of dissolving fibrin of blood clots and performs essential functions during reproductive processes such as extracellular matrix remodeling, modulating follicular development, corpus luteum formation, and weakening the follicle wall to promote ovulation [39, 53, 69-71]. Lastly, the high level of apolipoprotein-1 (APOA1) participates in the cholesterol and triglyceride transportation, having positive mitogenic and angiogenic effects [72], which is beneficial to follicle development.

In summary, this study describes, for the first time, the proteome profile of the equine FF collected during anovulatory (SAN) and ovulatory (SOV, SUM, and FOV) seasons. Functional analyses revealed differences that may be essential to better characterization of reproductive seasonality in mares. The findings show that SUM follicular fluid proteome of dominant follicles (30-34 $\mathrm{mm}$ ) differs from other seasons and appears to be characterized by a higher fluidity. This former characteristic may allow a more efficient natural flux of biological factors to the oocyte, influencing its maturation, ovulation, and safe transport to the oviduct. While the "coagulation and complement" cascades were confirmed as the prime signatures of the FF proteome, the balance between prothrombin, plasminogen, and coagulation factor XII proteins seemed crucial for the fluidity of the FF at the peak moment of the ovulatory season.

\section{Additional file}

Additional file 1: Table S1. All seasonal proteome datasets, with full protein annotations. (ODS $1926 \mathrm{~kb}$ )

Acknowledgements

The authors thank Dr. S B Park and Mrs. C S Steadman for their technical assistance during protein preparations and gel electrophoresis. 


\section{Funding}

Funded by Southern Illinois University, Carbondale, IL; Institute of Genomics, Biocomputing and Bioinformatics at Mississippi State University; NIH MS-IDeA Network of Biomedical Research Excellence award 4P20GM103476-15: and USDA-ARS Biophotonics Initiative (8-6402-3-018). The mass spectrometry proteomics analysis was performed at the Institute for Genomics, Biocomputing and Biotechnology, Mississippi State University, with partial support from Mississippi Agriculture and Forestry Experimental Station. GAD is the recipient of a PhD sandwich from the Coordination for the Improvement of Higher Education Personnel (CAPES; grant \#PPGMV-UFRRJ\#88881.133485/2016-01), Brazil. GM I is the recipient of a PhD scholarship from the Ministry of Higher Education \& Scientific Research, Baghdad, Iraq

\section{Availability of data and materials}

All data generated and analyzed in this study are included in this published manuscript.

\section{Authors' contributions}

GAD and GMI conducted the experiment, analyzed data, and wrote the first draft of the paper; OP, TP and DGP performed proteomics analyses; JMF and GAD conducted functional bioinformatic analyses; JCFJ, STW, and PLR assisted in experimental design and data interpretation; ELG, GMI, and JMF contributed to the design and execution of all experiments, and revised the manuscript. All authors read and approved the final draft.

\section{Ethics approva}

All animal care and experimental protocols used in this study were approved by the institutional animal care and the ethic committee of Southern Illinois University.

\section{Consent for publication}

Not applicable.

\section{Competing interests}

The authors declare that they have no competing interests.

\section{Publisher's Note}

Springer Nature remains neutral with regard to jurisdictional claims in published maps and institutional affiliations.

\section{Author details}

${ }^{1}$ Department of Animal Science, Food and Nutrition, Southern Illinois University, Carbondale, IL, USA. ²Department of Reproduction and Animal Evaluation, Federal Rural University of Rio de Janeiro, Seropédica, Brazil. ${ }^{3}$ Department of Surgery and Obstetrics, College of Veterinary Medicine, University of Baghdad, Baghdad, Iraq. ${ }^{4}$ Institute for Genomics, Biocomputing and Bioinformatics, University, Mississippi State, Oxford, MS, USA. ${ }^{5}$ Department of Animal and Dairy Sciences, Mississippi State University, Mississippi State, 4025 Wise Center, PO Box 9815, Mississippi State, MS 39762, USA.

\section{Received: 31 December 2018 Accepted: 26 February 2019} Published online: 06 March 2019

\section{References}

1. Assidi M, Montag M, Van Der Ven K, Sirard M-A. Biomarkers of human oocyte developmental competence expressed in cumulus cells before ICSI: a preliminary study. J Assist Reprod Genet. 2011;28(2):173-88.

2. Revelli A, Delle Piane L, Casano S, Molinari E, Massobrio M, Rinaudo P. Follicular fluid content and oocyte quality: from single biochemical markers to metabolomics. Reprod Biol Endocrinol. 2009;7(1):40.

3. Fahiminiya S, Gérard N. Le liquide folliculaire chez les mammifères Gynécologie Obstétrique \& Fertilité. 2010;38(6):402-4.

4. Ginther O. Pitfalls in animal reproduction research: how the animal guards nature's secrets. Theriogenology. 2013;80(3):169-75.

5. Nagy P, Guillaume D, Daels P. Seasonality in mares. Anim Reprod Sci. 2000 60:245-62.

6. Ginther O, Gastal E, Gastal M, Beg M. Seasonal influence on equine follicle dynamics. Anim Reprod. 2004;1(1):31-44.

7. Donadeu F, Watson E. Seasonal changes in ovarian activity: lessons learnt from the horse. Anim Reprod Sci. 2007;100(3-4):225-42.
8. Ginther O. Folliculogenesis during the transitional period and early ovulatory season in mares. J Reprod Fertil. 1990;90(1):311-20.

9. Gastal E, Gastal M, Donadeu F, Acosta T, Beg M, Ginther O. Temporal relationships among $\mathrm{LH}$, estradiol, and follicle vascularization preceding the first compared with later ovulations during the year in mares. Anim Reprod Sci. 2007;102(3-4):314-21.

10. Ishak GM, Bashir ST, Dutra GA, Gastal GDA, Gastal MO, Cavinder CA, et al. In vivo antral follicle wall biopsy: a new research technique to study ovarian function at the cellular and molecular levels. Reprod Biol Endocrinol. 2018;16(1):71.

11. Arashiro EK, Palhao MP, Wohlres-Viana S, Siqueira LG, Camargo LS, Henry M, et al. In vivo collection of follicular fluid and granulosa cells from individual follicles of different diameters in cattle by an adapted ovum pick-up system. Reprod Biol Endocrinol. 2013;11(1):73.

12. Tungal SS, Swamy MN, Honnappa T, Bhaskaran R. Ovarian antral follicular dynamics and follicular fluid composition in non-descript goats of Karnataka. Theriogenology Insight. 2014;4(2):49.

13. Regiani T, Cordeiro FB. da Costa LdVT, Salqueiro J, Cardozo K, Carvalho VM et al. follicular fluid alterations in endometriosis: label-free proteomics by MSE as a functional tool for endometriosis. Syst Biol Reprod Med. 2015; 61(5):263-76.

14. Turco L, Guimarães E, Cordeiro FB, de Carvalho Lopes PH, Gozzo FC, Pilau EJ, et al. Proteomic analysis of follicular fluid from women with and without endometriosis: new therapeutic targets and biomarkers. Mol Reprod Dev. 2013;80(6):441-50

15. Zachut M, Sood P, Levin Y, Moallem U. Proteomic analysis of preovulatory follicular fluid reveals differentially abundant proteins in less fertile dairy cows. J Proteome. 2016;139:122-9.

16. Ali A, Derar $\mathrm{R}$, Hussein $\mathrm{H}$. Seasonal variation of the ovarian follicular dynamics and luteal functions of sheep in the subtropics. Theriogenology. 2006;66(2):463-9.

17. Yie S-M, Brown G, Liu G-Y, Collins J, Daya S, Hughes E, et al. Melatonin and steroids in human pre-ovulatory follicular fluid: seasonal variations and granulosa cell steroid production. Hum Reprod. 1995;10(1):50-5.

18. Valckx S, Arias-Alvarez M, De Pauw I, Fievez V, Vlaeminck B, Fransen E, et al. Fatty acid composition of the follicular fluid of normal weight, overweight and obese women undergoing assisted reproductive treatment: a descriptive cross-sectional study. Reprod Biol Endocrinol. 2014;12(1):13.

19. Brüssow KP, Rátky J, Torner $\mathrm{H}$, et al. Et al. follicular and oocyte development in gilts of different age. Acta Vet Hung. 2002;50(1):101-10.

20. Algriany O, Bevers M, Schoevers E, Colenbrander B, Dieleman S. Follicle sizedependent effects of sow follicular fluid on in vitro cumulus expansion, nuclear maturation and blastocyst formation of sow cumulus oocytes complexes. Theriogenology. 2004;62(8):1483-97.

21. Ferrazza RA, Garcia HDM, EMdS S, Mihm Carmichael M, FFd S, Burchmore R, et al. Quantitative proteomic profiling of bovine follicular fluid during follicle development. Biol Reprod. 2017;97(6):835-49.

22. Fu Q, Huang $Y$, Wang $Z$, Chen F, Huang D, Lu Y, et al. Proteome profile and quantitative proteomic analysis of buffalo (Bubalusbubalis) follicular fluid during follicle development. Int J Mol Sci. 2016;17(5):618.

23. Chen F, Spiessens C, D'Hooghe T, Peeraer K, Carpentier S. Follicular fluid biomarkers for human in vitro fertilization outcome: proof of principle. Proteome Sci. 2016;14(1):17.

24. Oh JW, Kim SK, Cho KC, Kim MS, Suh CS, Lee JR, et al. Proteomic analysis of human follicular fluid in poor ovarian responders during in vitro fertilization. Proteomics. 2017:17(6).

25. Bijttebier J, Tilleman K, Dhaenens M, Deforce D, Van Soom A, Maes D. Comparative proteome analysis of porcine follicular fluid and serum reveals that excessive a2-macroglobulin in serum hampers successful expansion of cumulus-oocyte complexes. Proteomics. 2009;9(19):4554-65.

26. Ducolomb Y, González-Márquez H, Fierro R, Jiménez I, Casas E, Flores D, et al. Effect of porcine follicular fluid proteins and peptides on oocyte maturation and their subsequent effect on in vitro fertilization. Theriogenology. 2013;79(6):896-904.

27. Fahiminiya S, Reynaud K, Labas V, Batard S, Chastant-Maillard S, Gérard N. Steroid hormones content and proteomic analysis of canine follicular fluid during the preovulatory period. Reprod Biol Endocrinol. 2010;8(1):132.

28. Fahiminiya S, Labas V, Roche S, Dacheux J-L, Gérard N. Proteomic analysis of mare follicular fluid during late follicle development. Proteome Sci. 2011;9(1):54.

29. Petrucci B, Wolf C, Arlas T, Santos G, Estanislau J, Fiala S, et al. Proteomics of mare follicular fluid during follicle development. Journal of Equine Veterinary Science. 2014;34(1):115-6. 
30. Gastal E, Gastal M, Bergfelt D, Ginther O. Role of diameter differences among follicles in selection of a future dominant follicle in mares. Bio Reprod. 1997;57(6):1320-7.

31. Feugang JM, Rodriguez-Munoz JC, Willard ST, Bathgate RA, Ryan PL. Examination of relaxin and its receptors expression in pig gametes and embryos. Reprod Biol Endocrinol. 2011;9:10. https://doi.org/10.1186/14777827-9-10

32. Takáč T, Vadovič P, Pechan T, Luptovčiak I, Šamajová O, Šamaj J. Comparative proteomic study of Arabidopsis mutants mpk4 and mpk6. Sci Rep. 2016;6:28306

33. Takáč T, Šamajová O, Pechan T, Luptovčiak I, Šamaj J. Feedback microtubule control and microtubule-actin cross-talk in Arabidopsis revealed by integrative proteomic and cell biology analysis of KATANIN 1 mutants. Mol Cell Proteomics. 2017;16(9):1591-609.

34. Feist $P$, Hummon AB. Proteomic challenges: sample preparation techniques for microgram-quantity protein analysis from biological samples. Int J Mol Sci. 2015;16(2):3537-63

35. Jiang $L$, He L, Fountoulakis M. Comparison of protein precipitation methods for sample preparation prior to proteomic analysis. J Chromatogr A. 2004; 1023(2):317-20.

36. Santa C, Anjo SI, Manadas B. Protein precipitation of diluted samples in SDScontaining buffer with acetone leads to higher protein recovery and reproducibility in comparison with TCA/acetone approach. Proteomics. 2016;16(13):1847-51

37. Lewandowska AE, Macur K, Czaplewska P, Liss J, Łukaszuk K, Ołdziej S. Qualitative and quantitative analysis of proteome and Peptidome of human follicular fluid using multiple samples from single donor with LC-MS and SWATH methodology. J Proteome Res. 2017;16(8):3053-67.

38. Shen X, Liu X, Zhu P, Zhang Y, Wang J, Wang Y, et al. Proteomic analysis of human follicular fluid associated with successful in vitro fertilization. Reprod Biol Endocrinol. 2017;15(1):58. https://doi.org/10.1186/s12958-017-0277-y.

39. Ambekar AS, Nirujogi RS, Srikanth SM, Chavan S, Kelkar DS, Hinduja I, et al. Proteomic analysis of human follicular fluid: a new perspective towards understanding folliculogenesis. J Proteome. 2013;87:68-77.

40. Bianchi L, Gagliardi A, Landi C, Focarelli R, De Leo V, Luddi A, et al. Protein pathways working in human follicular fluid: the future for tailored IVF? Expert Rev Mol Med. 2016;18:e9.

41. Gakhar L, Bartlett JA, Penterman J, Mizrachi D, Singh PK, Mallampalli RK, et al. PLUNC is a novel airway surfactant protein with anti-biofilm activity. PLoS One. 2010;5(2):e9098.

42. Li K, Liu Y, Xia X, Wang L, Lu M, Hu Y, et al. Bactericidal/permeabilityincreasing protein in the reproductive system of male mice may be involved in the sperm-oocyte fusion. Reproduction. 2013;146(2):135-44.

43. Mou L, Xie N. Male infertility-related molecules involved in sperm-oocyte fusion. J Reprod Dev. 2017;63(1):1-7.

44. Paramio JM, Segrelles C, Ruiz S, Jorcano JL. Inhibition of protein kinase B (PKB) and PKC mediates keratin K10-induced cell cycle arrest. Mol Cell Biol. 2001;21(21):7449-59.

45. Muslin AJ, Klippel A, Williams LT. Phosphatidylinositol 3-kinase activity is important for progesterone-induced Xenopus oocyte maturation. Mol Cell Biol. 1993;13(11):6661.

46. Bagowski CP, Myers JW, Ferrell JE. The classical progesterone receptor associates with p42 MAPK and is involved in phosphatidylinositol 3-kinase signaling inXenopus oocytes. J Biol Chem. 2001;276(40):37708-14.

47. Hoshino T, Shimizu K, Honda T, Kawakatsu T, Fukuyama T, Nakamura T, et al. A novel role of Nectins in inhibition of the E-cadherin-induced activation of Rac and formation of cell-cell Adherens junctions. Mol Biol Cell. 2004;15(3): 1077-88.

48. Makker A, Goel MM, Nigam D, Mahdi AA, Das V, Agarwal A, et al. Aberrant Akt activation during implantation window in infertile women with intramural uterine fibroids. Reprod Sci. 2017;25(8):1243-53.

49. Markstrom E, Svensson E, Shao R, Svanberg B, Billig H. Survival factors regulating ovarian apoptosis--dependence on follicle differentiation. Reproduction. 2002;123(1):23-30.

50. Rodgers RJ, Irving-Rodgers HF, Russell DL. Extracellular matrix of the developing ovarian follicle. Reproduction. 2003;126(4):415-24.

51. Zamah AM, Hassis ME, Albertolle ME, Williams KE. Proteomic analysis of human follicular fluid from fertile women. Clin Proteomics. 2015;12(1):5.

52. Paula ARJ, Lobo MDP, Monteiro-Moreira ACO, Moreira RA, Melo CHS, SouzaFabjan JMG, et al. Proteomic analysis of follicular fluid from tropicallyadapted goats. Anim Reprod Sci. 2018;188:35-44.
53. Jarkovska K, Martinkova J, Liskova L, Halada P, Moos J, Rezabek K, et al. Proteome mining of human follicular fluid reveals a crucial role of complement cascade and key biological pathways in women undergoing in vitro fertilization. J Proteome Res. 2010;9(3):1289-301. https://doi.org/10. 1021/pr900802u

54. de Agostini Al, Dong J-C, de Vantéry AC, Ramus M-A, Dentand-Quadri I, Thalmann S, et al. Human follicular fluid heparan sulfate contains abundant 3-O-sulfated chains with anticoagulant activity. J Biol Chem. 2008;283(42): 28115-24.

55. Acosta T, Beg M, Ginther O. Aberrant blood flow area and plasma gonadotropin concentrations during the development of dominant-sized transitional anovulatory follicles in mares. Biol Reprod. 2004;71(2):637-42.

56. Watson E, Al-Zi'abi M. Characterization of morphology and angiogenesis in follicles of mares during spring transition and the breeding season. Reproduction. 2002;124(2):227-34.

57. Anahory T, Dechaud H, Bennes R, Marin P, Lamb NJ, Laoudj D. Identification of new proteins in follicular fluid of mature human follicles. Electrophoresis. 2002;23(7-8):1197-202.

58. Ebisch IM, Thomas CM, Wetzels AM, Willemsen WN, Sweep FC, SteegersTheunissen RP. Review of the role of the plasminogen activator system and vascular endothelial growth factor in subfertility. Fertil Steril. 2008;90(6): 2340-50.

59. Hanrieder J, Zuberovic A, Bergquist J. Surface modified capillary electrophoresis combined with in solution isoelectric focusing and MALDITOF/TOF MS: a gel-free multidimensional electrophoresis approach for proteomic profiling - exemplified on human follicular fluid. J Chromatogr A. 2009;1216(17):3621-8.

60. Curry TE Jr, Osteen KG. The matrix metalloproteinase system: changes, regulation, and impact throughout the ovarian and uterine reproductive cycle. Endocr Rev. 2003;24(4):428-65.

61. Silverman GA, Bird PI, Carrell RW, Coughlin PB, Gettins PG, Irving Jl, et al. The serpins are an expanding superfamily of structurally similar but funtionally diverse proteins: evolution, mechanism of inhibition, novel functions, and a revised nomenclature. J Biol Chem. 2001;276(36):33293-6.

62. Szklarczyk D, Franceschini A, Wyder S, Forslund K, Heller D, Huerta-Cepas J, et al. STRING v10: protein-protein interaction networks, integrated over the tree of life. Nucleic Acids Res. 2015:43(D1):D447-D52.

63. Goldsack NR, Chambers RC, Dabbagh K, Laurent GJ. Molecules in focus thrombin. Int J Biochem Cell Biol. 1998;30(6):641-6.

64. Roach LE, Petrik JJ, Plante L, LaMarre J, Gentry PA. Thrombin generation and presence of thrombin receptor in ovarian follicles. Biol Reprod. 2002;66(5): $1350-8$

65. Hofman Z, de Maat S, Hack CE, Maas C. Bradykinin: inflammatory product of the coagulation system. Clin Rev Allergy Immunol. 2016;51(2):152-61.

66. Hellberg P, Larson L, Olofsson J, Hedin L, Brännström M. Stimulatory effects of bradykinin on the ovulatory process in the in vitro-perfused rat ovary. Biol Reprod. 1991;44(2):269-74.

67. Brännström M, Hellberg P. Bradykinin potentiates LH-induced fofficular rupture in the rat ovary perfused in vitro. Hum Reprod. 1989;4(5):475-81.

68. Yoshimura Y, Espey L, Hosoi Y, Adachi T, Atlas S, Ghodgaonkar R, et al. The effects of bradykinin on ovulation and prostaglandin production by the perfused rabbit ovary. Endocrinology. 1988;122(6):2540-6.

69. Cao M, Nicola E, Portela VM, Price CA. Regulation of serine protease inhibitor-E2 and plasminogen activator expression and secretion by follicle stimulating hormone and growth factors in non-luteinizing bovine granulosa cells in vitro. Matrix Biol. 2006;25(6):342-54.

70. Beers WH. Follicular plasminogen and plasminogen activator and the effect of plasmin on ovarian follicle wall. Cell. 1975;6(3):379-86.

71. Bianchi L, Gagliardi A, Campanella G, Landi C, Capaldo A, Carleo A, et al. A methodological and functional proteomic approach of human follicular fluid en route for oocyte quality evaluation. J Proteome. 2013;90:61-76.

72. von Otte S, Paletta JR, Becker S, König S, Fobker M, Greb RR, et al. Follicular fluid high density lipoprotein-associated sphingosine 1-phosphate is a novel mediator of ovarian angiogenesis. J Biol Chem. 2006;281(9):5398-405. 